\title{
ENDEMIC DISEASES OF THE TRANSBAIKAL REGION
}

\author{
Maria. A. Solodukhina ${ }^{1}$ \\ Larisa A. Mikhailova ${ }^{2}$ \\ Svetlana E. Lapa ${ }^{3}$ \\ Natalia M. Burlaka4
}

1. Institute of Natural Resources, Ecology and Cryology, Siberian Branch of the Russian Academy of Sciences.

2. Chita State Medical Academy of the Ministry of Health of the Russian Federation.

3. Office of the Federal Service for Supervision of Consumer Rights Protection and Welfare of the Population in the Trans-Baikal Territory, Chita State Medical Academy of the Ministry of Health of the Russian Federation, Chita, Russia.

4. Office of Rospotrebnadzor in the Trans-Baikal Territory, Head of the Organization and Support Department. Corresponding Author email: burlakanm@mail.ru.

\begin{abstract}
The urgency of the problem under investigation is due to the fact that the geochemistry of the Transbaikal Region is very diverse. The aim of the article was to characterize the main diseases associated with the geochemical features of the environment and to study the dynamics of primary and general morbidity associated with micronutrient deficiency in the Transbaikal Region. The leading methods of research are the analysis of Report Form No. 63 'Information on diseases associated with micronutrient deficiency', statistical processing of materials, and mapping. The highest level of endemic goiter occurrences is characteristic for 5 districts: Dulurginsky, Krasnokamensky, Kalarsky, Tungiro-Oleminsky and Tungokochensky. The analysis of the level of primary and general morbidity associated with iodine deficiency shows a marked tendency in the increase of diffuse (endemic), subclinical hypothyroidism and multinodular goitre cases in children, and the increase in diffuse (endemic) and multinodular (endemic) goiter among adolescents.
\end{abstract}

Keywords: endemic goiter, fluorosis, Keshan disease (selenium deficiency), Kashin-Beck disease.

\section{INTRODUCTION}

In the Transbaikal Region, there are areas with an excess or a shortage of some chemical elements in water, soil and other landscape components [9]. These territories are usually called biogeochemical provinces, and it is known that one of the risk factors for human health is the imbalance of micro- and macro elements in environmental components, characteristic for such areas [9; 11]. The great Russian geochemist, A.P. Vinogradov, wrote about the connection between biogeochemical provinces and the emergence of endemics as far back as the 1950s [5]. According to the Department of Biochemistry of Chita State Medical Academy, 14 geochemical provinces with a high concentration of a number of elements in the subsoil horizon (10 million samples) were singled out in the Eastern Zabaikalye: lead, zinc, copper, arsenic, mercury, molybdenum 
with gold, fluoride, boric, titanium, cobalt, nickel, manganese, as well as provinces with increased radioactivity and containing rare metals (tantalum, lanthanum, zirconium, niobium, germanium) [19]. Data analysis indicates that the geochemical environment features of the region are the cause of endemic diseases such as endemic goiter, fluorosis, Keshan selenium deficiency) and Kashin-Beck diseases.

The imbalance of selenium in the environmental components leads to the development of selenoses, and lack of selenium in human nutrition leads to the endemic disease - selenium-deficient cardiomyopathy, the Keshan disease, first registered in the north of China, in Keshan district in 1935 [19]. Keshan disease was first diagnosed in the Soviet Union in the Chita region in 1987 as an endemic disease. Eastern Zabaikalye is a zone of selenium deficiency - in a number of its regions, low concentrations of selenium in soil, water and food samples were identified [19]. A.V. Voshchenko and his co-authors in the study of the selenium content in drinking water in Chita did not find a sufficient amount of selenium which could be determined by the GOST method existing at that time [8]. The authors also found an extremely low content of selenium in flour for breadbaking, as well as in meat of farm animals and poultry [8]. A study of blood donors living in Chita showed the content of selenium in the red blood cells was significantly lower compared to residents of Khabarovsk and Moscow [19]. G.A. Dremina and M.V. Prokofieva showed that in conditions of selenium deficiency in the Transbaikal Region it is necessary to introduce a selenium additive into the diet [10].

Kashin-Beck's disease, described in 1856 by N.I. Kashin, is common among the population not only on the territory of the Urov river basin of the Transbaikal Region, but also in other areas of the Eastern Zabaikalye, and in the Zeya district of the Amur Region. For a century and a half of its etiology research, about 20 opinions and hypotheses were expressed. According to one of them, the disease is the result of an imbalance in the intake of macro- and microelements with water and food in certain localities (Table 1). Based on the works of V.I. Ivanov, A.V. Voshchenko, L.P. Nikitina, L.V. Zayko, N.N. Druzhkova a phosphate-manganese hypothesis was proposed. According to these authors, the content of mobile phosphate forms in the soils of endemic areas is 2.4 times higher compared to the regulations. The level of manganese in products of vegetable and animal origin (wheat flour, cabbage, potatoes, meat) produced in endemic areas of the disease is 1.5 times higher than the norm [12]. This served as the basis for the hypothesis on the modifying role of manganese and phosphorus in the development of this disease and for conducting research aimed at obtaining its experimental model [6]. In the opinion of A.V. Voshchenko and his co-authors the calcium-strontium hypothesis of Kashin-Beck disease does not find confirmation. They did not establish a significant correlation between the shifts in the $\mathrm{Ca} / \mathrm{Sr}$ ratio and the level of the disease (Table 2). The Transbaikal Territory is extremely heterogeneous in content of fluorides in the groundwater of various genetic types which are the main source of water supply, providing more than $90 \%$ of the population's need for drinking water [13].

The areas of Kharanor coal mine, the village of Sherlova Gora, the city of Krasnokamensk, and the villages of Nerchinskiy Zavod and Novokrucininsk display an increased fluorine content in groundwater [17]. Dental examination of children aged 1215 years showed that $88.4 \%$ have fluorosis teeth [3], and in the surveyed 502 children aged 6-7 years (residents of Krasnokamensk) have fluorosis of permanent teeth in $72 \%$ of cases [17]. Krasnokamensk is thus the focus of endemic fluorosis [18]. In the KharanorTurginsk basin of the southeast of the Transbaikal Region not only a high content of fluorine, but also of silicon was established [16], which leads to fluorosis and diseases of 
the musculoskeletal system in the population [15]. Information on the spread of endemic goiter among the population of Eastern Zabaikalye has more than a century of history. The dependence of iodine content in food products on its concentration in soil and the relationship between the spread of the disease among the population is proved by numerous studies. Foci of this disease in humans geographically coincide with its presence among domestic animals [20]. It manifests itself in both adults and children studies conducted by the branch of the Research Institute of Pediatrics in Chita showed that out of 1672 children living in the northern regions of Zabaikalye and the Ingodinskiy district of Chita were diagnosed with endemic goiter [22]. N.M. Shagieva conducted an experimental psychological study and found out that children with endemic goiter are prone to fatigue, unable to control attention and make efforts to complete tasks. [21] L.V. Anikina, V.N. Ivanov, L.P. Nikitin, A.C. Gomboeva showed that endemic goiter in the Transbaikal Region is developing against a background of iodine and selenium deficiency $[1 ; 2 ; 14]$.

The total morbidity rates among children and adolescents in 2009-2013 in the Transbaikal Region on the whole grew by 1.6 and 2 times respectively; the development trend is characterized as pronounced growth ( $\mathrm{T}=12.56$ and 18.71 , respectively) (Table 3 ). According to the analysis of the dynamics of primary morbidity associated with micronutrient deficiency, in 2009-2013 the growth of this pathology in children and adolescents was revealed (1.8 and 2 times, respectively); the development trend is characterized as expressed growth ( $\mathrm{T}=15.37$ and 18.38, respectively) (Table 4). The territories where the primary morbidity associated with micronutrient deficiency among children exceeds the regional figures are Gazimuro-Zavodskiy, Kalarskiy, Krasnochikoyskiy, Tungiro-Olekminskiy, Tungokochenskiy, Shelopuginskiy, Duldurginskiy districts and Chita (Figure 1 according to [4]).

Table 1. The content of chemical elements in the water of the Urov Region (mg / l) and cases of Kashin-Beck disease in villages [7].

\begin{tabular}{|c|c|c|c|c|c|c|c|c|}
\hline Settlements & $\begin{array}{c}\text { Kashin- } \\
\text { Beck cases } \\
(\%)\end{array}$ & $\mathrm{Pb}$ & $\mathrm{Zn}$ & $\mathrm{Mn}$ & $\mathrm{Fe}$ & $\mathrm{Mo}$ & $\mathrm{Cu}$ & $\mathrm{Ag}$ \\
\hline Malyshevo & 1 & 0,08 & 0,06 & 0,03 & 0,6 & 0,0007 & 0,004 & 0,004 \\
\hline Tergen & 2,5 & Traces & Traces & 0,03 & 0,7 & 0,001 & 0,002 & $\begin{array}{c}\text { Not } \\
\text { found }\end{array}$ \\
\hline Trubachevo & 28,8 & 0,001 & Traces & 0,005 & 0,3 & 0,0009 & 0,003 & Traces \\
\hline Korabl & 18,5 & 0,003 & Traces & 0,07 & 1,4 & 0,002 & 0,02 & Traces \\
\hline Dogje & 14,3 & 0,15 & 0,75 & 0,08 & 0,7 & 0,001 & 0,01 & 0,004 \\
\hline Igdocha & 26,0 & Traces & Traces & 0,08 & 1,0 & 0,003 & 0,005 & $\begin{array}{c}\text { Not } \\
\text { found }\end{array}$ \\
\hline Tajna & 30,4 & 0,04 & 0,3 & 0,03 & 1,2 & Traces & 0,003 & $\begin{array}{c}\text { Not } \\
\text { found }\end{array}$ \\
\hline
\end{tabular}




\begin{tabular}{|c|c|c|c|c|c|c|c|c|}
\hline Ushmun & 28,0 & 0,03 & 0,03 & 0,08 & 0,28 & 0,004 & 0,02 & Traces \\
\hline Elgino & 8,1 & 0,06 & Traces & 0,03 & 0,6 & 0,0008 & 0,004 & 0,004 \\
\hline Burucan & 37,7 & 0,04 & 0,3 & 0,04 & 0,3 & 0,0008 & 0,002 & 0,001 \\
\hline Batakan & 33,7 & 0,01 & Traces & 0,04 & 0,3 & 0,009 & 0,002 & 0,0003 \\
\hline Banshchikovo & 22,5 & Traces & Traces & 0,06 & 1,25 & Traces & 0,001 & $\begin{array}{c}\text { Not } \\
\text { found }\end{array}$ \\
\hline Malyshevo & 1,0 & 0,01 & Traces & 0,03 & 1,1 & Traces & 0,002 & 0,0001 \\
\hline Kopun & 8,0 & Traces & Traces & Traces & 1,2 & 0,001 & 0,005 & $\begin{array}{c}\text { Not } \\
\text { found }\end{array}$ \\
\hline
\end{tabular}

Table 2. The ratio of calcium-strontium levels in soils (mg / $\mathrm{kg}$ ) and the disease level (\%) in villages [7].

\begin{tabular}{|c|c|c|c|c|}
\hline Settlements & $\begin{array}{c}\text { Kashin-Beck } \\
\text { cases (\%) }\end{array}$ & $\mathrm{Ca}$ & $\mathrm{Sr}$ & $\mathrm{Ca} / \mathrm{Sr}$ \\
\hline Krasnoyarovo & 18,8 & $16,0 \pm 4,0$ & $5,1 \pm 0,8$ & 3,2 \\
\hline Dogje & 14,3 & $41,0 \pm 7,0$ & $4,7 \pm 0,7$ & 8,7 \\
\hline Ushmun & 28,1 & $35,1 \pm 7,0$ & $4,9 \pm 0,8$ & 7,2 \\
\hline Korabl & 18,5 & $37,0 \pm 6,0$ & $5,0 \pm 1,0$ & 7,4 \\
\hline Trubachevo & 28,8 & $53,0 \pm 9,0$ & $2,7 \pm 0,4$ & 19,9 \\
\hline Batakan & 33,7 & $55,9 \pm 9,0$ & $3,1 \pm 0,5$ & 18,1 \\
\hline Burucan & 37,7 & $84,1 \pm 14,5$ & $4,3 \pm 0,7$ & 19,8 \\
\hline Tajna & 30,4 & $115,1 \pm 19,1$ & $2,6 \pm 0,4$ & 44,2 \\
\hline Gaz-zavod & 22,6 & $132,0 \pm 22,0$ & $3,9 \pm 0,6$ & 33,3 \\
\hline Yamkun & 19,6 & $350,0 \pm 59,0$ & $5,1 \pm 0,8$ & 69,1 \\
\hline Kopun & 8,0 & $141,1 \pm 23,1$ & $2,6 \pm 0,4$ & 54,2 \\
\hline Shelopugino & 27,3 & $102,2 \pm 16,2$ & $2,1 \pm 0,3$ & 49,1 \\
\hline Elgino & 8,1 & $15,0 \pm 3,0$ & $2,5 \pm, 05$ & 6,0 \\
\hline
\end{tabular}

The analysis of primary morbidity associated with iodine deficiency in nosological forms showed that in 2009-2013, a marked tendency to an increase in the diffuse (endemic) goiter cases in children by $81.98 \%$, in multinodular (endemic) goiter by $66.66 \%$, and subclinical hypothyroidism cases were doubled. Among adolescents, there 
was a two-fold increase in the diffuse (endemic) goiter, and an increase in multinodular (endemic) goiter cases by 1.9 times (Table 5).

Table 3. Dynamics of the overall morbidity associated with micronutrient deficiency in 2009-2013 (per 1000 people).

\begin{tabular}{|c|c|c|c|c|c|c|c|c|}
\hline \multirow[b]{2}{*}{ Indicators } & \multicolumn{5}{|c|}{ Years } & \multirow[b]{2}{*}{ СMУ } & \multirow{2}{*}{$\begin{array}{c}\text { Growth/decline } \\
\text { rates } \\
(\%)\end{array}$} & \multirow[b]{2}{*}{$\mathrm{T}$} \\
\hline & 2009 & 2010 & 2011 & 2012 & 2013 & & & \\
\hline Children & 6,46 & 7,80 & 10,04 & 11,44 & 10,44 & 9,25 & 61,61 & 12,56 \\
\hline Adolescents & 20,43 & 26,46 & 25,84 & 38,11 & 43,47 & 30,26 & Double growth & 18,71 \\
\hline
\end{tabular}

Table 4. Dynamics of the primary morbidity associated with micronutrient deficiency in 2009-2013 (per 1000 people).

\begin{tabular}{|c|c|c|c|c|c|c|c|}
\hline Population & \multicolumn{5}{|c|}{ Years } & Growth/decline & $\mathrm{T}$ \\
\cline { 2 - 8 } category & 2009 & 2010 & 2011 & 2012 & 2013 & rates (\%) & \\
\hline $\begin{array}{c}\text { Children } \\
(0-14)\end{array}$ & 1,66 & 2,61 & 3,63 & 4,59 & 3,06 & 84,3 & 15,37 \\
\hline $\begin{array}{c}\text { Adolescents } \\
(15-18)\end{array}$ & 4,37 & 5,55 & 5,44 & 8,86 & 8,78 & 101,1 & 18,38 \\
\hline
\end{tabular}

The indicators of the newly diagnosed diffuse goiter cases among children and adolescents in 2013 were 2.93 and 8.20, respectively, which is 2.43 and 5.96 higher than in Russia and 2.78 and 7.99 in the Siberian Federal District, respectively (per 1000 people). The level of morbidity associated with micronutrient deficiency among the total population in 2013 in the Transbaikal Region is shown in Fig. 2. The analysis gives grounds to believe that the highest level of endemic goiter cases is characteristic for 5 districts of the region: Duldurginskiy, Krasnokamenskiy, Kalarskiy, Tungiro-Oleminskiy and Tungokochenskiy (Fig. 2).

Table 5. Dynamics of the primary morbidity associated with micronutrient deficiency according to nosological forms and population groups in 2009-2013 (per 1000 people).

\begin{tabular}{|c|c|c|c|c|c|c|c|}
\hline \multirow{2}{*}{ Nosology } & Population & \multicolumn{5}{|c|}{ Years } & $\begin{array}{c}\text { Growth/decline } \\
\text { rates (\%) }\end{array}$ \\
\cline { 3 - 8 } & children & 0,08 & 0,05 & 0,03 & 0,07 & 0,03 & $-62,5$ \\
\cline { 2 - 8 } $\begin{array}{c}\text { Congenital } \\
\text { iodine } \\
\text { deficiency } \\
\text { Syndrome }\end{array}$ & adolescents & 0,02 & 0,05 & 0,10 & 0,02 & 0 & -100 \\
\hline $\begin{array}{c}\text { Diffuse } \\
\text { (endemic) } \\
\text { goiter }\end{array}$ & children & 1,61 & 2,13 & 3,49 & 4,46 & 2,93 & 81,98 \\
\cline { 2 - 8 } & adolescents & 3,93 & 4,52 & 4,75 & 8,49 & 8,20 & 108,7 \\
\hline $\begin{array}{c}\text { Multinodular } \\
\text { (endemic) goiter }\end{array}$ & children & 0,03 & 0,45 & 0,06 & 0,02 & 0,05 & 66,66 \\
\cline { 2 - 8 } & adolescents & 0,19 & 0,22 & 0,43 & 0,12 & 0,37 & 94,7 \\
\hline $\begin{array}{c}\text { Subclinical } \\
\text { hypothyroidism }\end{array}$ & children & 0,02 & 0,06 & 0,07 & 0,10 & 0,05 & 150,0 \\
\cline { 2 - 8 } & adolescents & 0,06 & 0,05 & 0,14 & 0,20 & 0,05 & $-16,66$ \\
\hline \multirow{2}{*}{ Thyrotoxicosis } & children & 0,01 & 0,01 & 0,02 & 0,01 & 0 & -100 \\
\cline { 2 - 7 } & adolescents & 0,04 & 0 & 0,02 & 0,10 & 0,05 & 25,0 \\
\hline
\end{tabular}




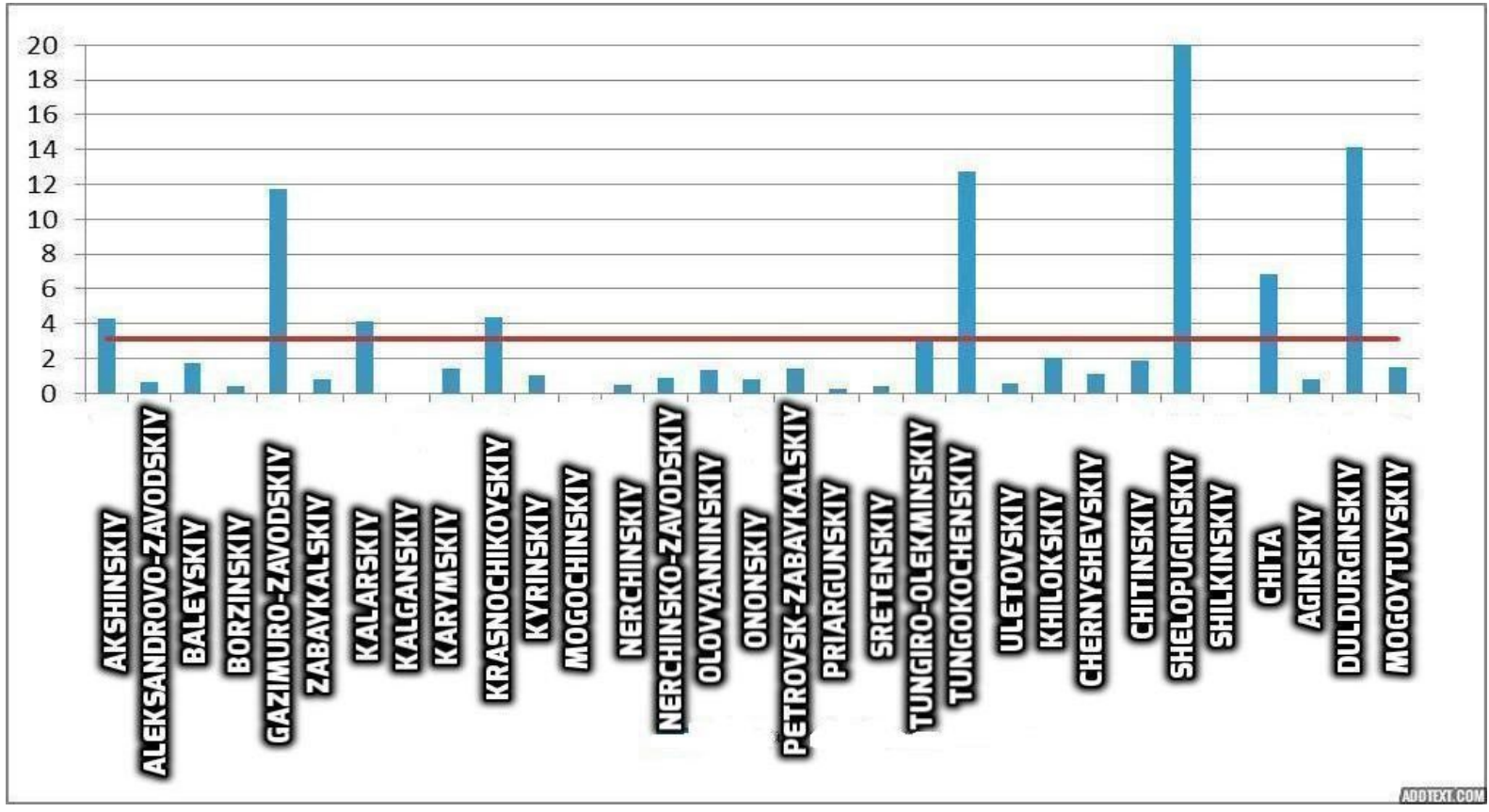

Fig. 1. Territories of the region with an excessive marginal rate of the newly diagnosed morbidity associated with micronutrient deficiency among children (0-14 years) in 2013.

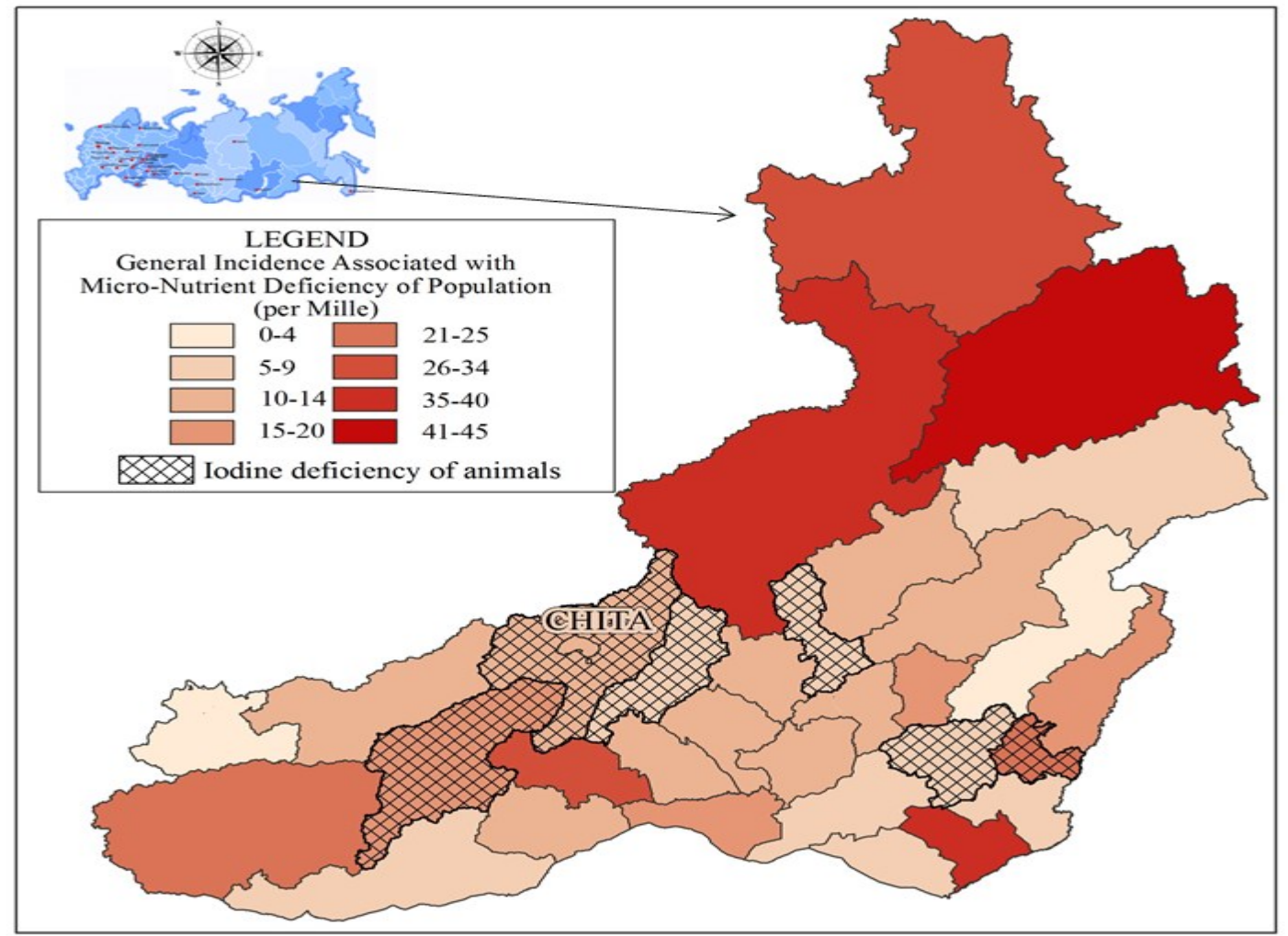

Fig. 2. Indicators of the general morbidity associated with micronutrient deficiency among the total population in 2013 in the districts of the Transbaikal Region, and iodine deficiency in domestic animals. 


\section{RESULTS}

The geochemical situation in the Transbaikal Region is quite diverse, which leads to the endemic diseases such as Keshan and Kashin-Beck diseases, endemic goiter and fluorosis. The assessment of the general morbidity associated with iodine deficiency showed that children and adolescents have a marked tendency in the increase of diffuse (endemic) goiter and subclinical hypothyroidism cases. The analysis of the level of newly diagnosed disease cases shows a pronounced tendency in the increase of diffuse (endemic), subclinical hypothyroidism and multinodular goiter cases in children, and in the increase in diffuse (endemic) and multinodular (endemic) goiter cases among adolescents. In Kalarskiy, Krasnochikoyskiy, Tungokochenskiy, Shelopuginskiy, Duldurginskiy districts and in the city of Chita in children, and in the Tungiro-Olekminskiy Kalarskiy, Nerchinsk-Zavodskiy, Shelopuginskiy and Krasnochikoyskiy districts among adolescents the total and newly diagnosed morbidity associated with micronutrient deficiency exceeds the marginal levels.

\section{CONCLUSIONS}

The research materials can be of use to medical scientists, teachers and students, as well as to teachers and students of natural sciences universities, and specialists in the field of geochemistry, biogeochemistry and human ecology. On the territory of the Russian Federation there are regions displaying (besides the general risk factors) a lack/excess of microelements in the environment, leading to the formation of specific prenosological and pathological conditions. The study of such regions plays an important role in the prevention and early diagnosis of these diseases.

\section{REFERENCES}

1. Abdullaev, E. V. (ed.) (2008). Trudovaya migratsiya kak fenomen razvivayushchegosya obshchestva [Labor migration as a phenomenon of a developing society]. In: Trudovaya migratsiya $\mathrm{v}$ Respublike Uzbekistan: sotsialnye, pravovye $\mathrm{i}$ gendernye aspekty: sbornik statey [Labor migration in the Republic of Uzbekistan: social, legal and gender aspects: collection of works]. pp. 12-23. Tashkent.

2. Anikina, L.V. Ecology of selenium and its importance in the body / L.V. Anikina // Transbaikal medical bulletin. -1996. - №1. - P. 46-48.

3. Anikina, L.V. Clinical and biochemical features of endemic goiter in the Transbaikal Region. I. Symptomatics and Functional State of the Thyroid Gland in Patients. L.V. Anikina, G.A. Dremina, M.P. Soshnyanina / / Ecologically dependent diseases (biochemistry, pharmacology, clinical picture): theses of the Russian scientific-practical conference. - Chita, 1997. - P. 64-65.

4. Belousov, A.V. Foci of fluorosis in the southeastern Zabaikalye / A.V. Belousov, G.I. Frolova // Ecological intoxications: biochemistry, pharmacology, clinical picture: theses of the Russian scientific conference. - Chita, 1996. - P. 17-18.

5. Burlaka, N.M. Morbidity of the population of the Transbaikal Region associated with micronutrient deficiency in 2009-2013: information review / N.M. Burlaka, S.E. Lapa, A.A. 
Shramko. - Chita, 2014. - 36 p.

6. Vinogradov, A.P. Geochemistry of rare and dispersed elements in soils / A.P. Vinogradov. - M., 1950. - 279 p.

7. Influence of the biogeochemical environment on the manifestation of Kashin-Beck disease. - Chita, 1984. - 99 p.

8. Voshchenko, A.V. To the etiology of Kashin-Beck disease / A.V. Voshchenko, V.N. Chugaev, S.I. Vaistukh, V.S. Butko // Pediatrics: diagnostics and treatment: theses of the scientific-practical conference. Chita, 1988. - P. 20-23.

9. Voshchenko, A.V. Geochemical situation in the foci of Keshan disease / A.V. Voshchenko, V.N. Chugaeva, L.I. Govorina, V.V. Krasnitskaya // Ecological intoxications: biochemistry, pharmacology, clinical picture: theses of the Russian scientific conference. - Chita, 1996. - P. 20-21.

10. Gorlachev, V.P. Ecology of Zabaikalye and human health. / Gorlachev V.P., Serdtsev M.I. - Chita, 2003. - 96 p.

11. Dremina, G.A. Limits of adequate and safe consumption of selenium in biogeochemical selenium-deficient provinces / G.A. Dremina, M.V. Prokofieva // Ecologically dependent diseases (biochemistry, pharmacology, clinical picture). Abstracts of the Russian scientific-practical conference. Chita, 1997. - P. 192-193.

12. Zhestyanikov, A.L. The imbalance of some macro- and microelements as a risk factor for diseases of the cardiovascular system in the north / A.L. Zhestyanikov // Human Ecology. - 2005. - No. 9. - P. 19-25.

13. Zayko, L.V. The content of phosphorus and manganese in the biogeochemical chain of endemic areas with Kashin-Beck disease / L.V. Zaiko // Influence of the biogeochemical environment on the manifestation of Kashin-Beck disease. - Chita, 1984. - P. 12-14.

14. Zamana, L.V. Domestic and drinking water as a factor of endemic and nonspecific diseases of the population of the Chita Region / L.V. Zaman, N.M. Gladkaya, Yu.V. Lesnikova // Geography and natural resources. - 1991. - No. 2. - P. 131-135

15. Ivanov, V.N. Clinical and biochemical features of endemic goiter in Zabaikalye. II. The state of lipid metabolism in persons suffering from this disease / V.N. Ivanov, L.P. Nikitina, L.V. Anikina, A.C. Gomboeva // Ecologically dependent diseases (biochemistry, pharmacology, clinical picture): theses of the Russia scientific-practical conference. Chita, 1997. - P. 66-67.

16. Kuzina, I.V. Hygienic assessment of the southeastern Zabaikalye from the position of endemic fluorosis: doctoral thesis in Biol. Sciences / I.V. Kuzina. - Chita, 2004. - 154 p.

17. Kuzina, I.V. Frequency and intensity of fluorosis and caries with a mathematical prognosis of morbidity in an endemic foci. Kuzina, E.A. Radnaev, M.F. Savchenko // Ecological intoxications: biochemistry, pharmacology, clinical picture: theses of the Russian scientific conference. - Chita, 1996. - P. 52-54.

18. Miloserdov, A.Ya. Influence of the environment on human health / A.Ya. Miloserdov, Yu.A. Belozertsev // Ecological intoxications: biochemistry, pharmacology, clinical picture: theses of the Russian scientific conference. - Chita, 1996. - P. 5-9.

19. Mineral composition of the tooth and severity of fluorosis / Ivanov VN. [et al.] // 
Ecological intoxications: biochemistry, pharmacology, clinical picture: theses of the Russian scientific conference. - Chita, 1996. - P. 42.

20. Selenium in the life of man and animals. - M., 1995. - 242 p.

21. Serdtsev, M.I. Ecology of Zabaikalye and human health / M.I. Serdtsev. - Chita, 2001. $-68 \mathrm{p}$.

22. Shagieva, N.M. Attention indicators in schoolchildren in conditions of goiter endemia of Zabaikalye / NM. Shagieva // Ecologically dependent diseases (biochemistry, pharmacology, clinical picture: theses of the Russian scientific conference) - Chita, 1997. - P. 176-177.

23. Endemic goiter in children in the Transbaikal Region / Bisharova G.I. [et al.]. // Ecologically dependent diseases (biochemistry, pharmacology, clinical picture: theses of the Russian scientific conference. - Chita, 1997. - P. 139. 